\title{
A survey of dairy farmers' practices and attitudes towards some aspects of arable-land management in the Darling Downs and South Burnett regions of Queensland
}

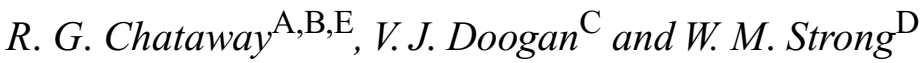 \\ A Mutdapilly Research Station, Department of Primary Industries, MS 825, Peak Crossing, Qld 4306, Australia. \\ ${ }^{B}$ School of Natural and Rural Systems Management, The University of Queensland, Gatton, Qld 4343, Australia. \\ ${ }^{\mathrm{C}}$ Animal Research Institute, Department of Primary Industries, 665 Fairfield Road, Yeerongpilly, Qld 4105, Australia. \\ ${ }^{\mathrm{D}}$ Farming Systems Institute, Department of Primary Industries, PO Box 2282, Toowoomba, Qld 4350, Australia. \\ ${ }^{\mathrm{E}}$ Author for correspondence; e-mail: robert.chataway@dpi.qld.gov.au
}

\begin{abstract}
The Darling Downs and Southern Inland Burnett are important geographical subregions of the Queensland dairy industry. The system of dairy farming in these subregions is unique in Australia in that it is based on grazed annual forage crops rather than pastures. When these soils were first cultivated up to 110 years ago they were inherently fertile. However, erosion and fertility decline has reduced their productive capacity and there is a need for the adoption of farming practices that are less exploitative. In February 1997, a survey was conducted to determine dairy farmers' practices and attitudes toward management strategies that were being recommended to grain farmers in the subtropical cereal belt for sustaining the soil resource base. These strategies included greater use of ley pastures, opportunistic double-cropping, zero-till planting and higher fertiliser inputs. We found that dairy farmers were generally familiar with and understanding of the potential benefits of these approaches to their farming enterprises. However, farmers raised a number of issues that need consideration in the transfer of these practices to dairy forage production. These included concerns that an increased emphasis on pastures would result in lower and less-reliable forage production; that double-cropping is practiced more out of necessity than in the belief it is a better way to farm; that zero tillage may not be suitable on clay soils that have been trampled by cattle and that farmers rely primarily on their own observations of crop performance to determine fertiliser use. These findings have particular implications for research and extension activities conducted with dairy farmers and are also relevant to work conducted with other cropping enterprises that incorporate grazing animals in their farming program.
\end{abstract}

\section{Introduction}

In 1995, the Darling Downs and Southern Inland Burnett produced 30\% of the State's milk supply (Kerr et al. 1996). This relative contribution has remained unchanged since industry deregulation in July 2000 (L. S. Mullins pers. comm.) and there are some sound reasons why dairying will continue and even expand there in the future. Farms in these regions are centrally located within the subtropical cereal grain belt (Webb et al. 1997), making them ideally placed to increase farm efficiency through greater use of purchased feeds (Ashwood et al. 1993); they face less pressure from urban development than those located in coastal south-eastern Queensland; and the Darling Downs is free of cattle ticks (Boophilus microplus) which incur a significant cost to farmers in the northern industry (Johnsson 1997).

When the study was conducted in 1997, 480 farms were located in the Darling Downs and 120 in the Southern Inland Burnett region (Fig. 1). The Darling Downs region slopes away to the west and south of the Great Dividing Range, while the other region is located north and east of the
Dividing Range. Overall, farms are located between latitudes $28^{\circ} 20^{\prime} \mathrm{S}$ and $26^{\circ} 00^{\prime} \mathrm{S}$, a distance of $300 \mathrm{~km}$. Rainfall is variable, with an annual coefficient of variation of about $25 \%$ (Clewett et al. 1999), and can be intense over the summer months (Rosenthal and White 1980). Annual evaporative demand is 2-3 times annual rainfall and highest in the west where rainfall is lowest. Rainfall is generally higher in the Burnett (700-800 mm/year) and more summer-dominant than the Darling Downs $(650-750 \mathrm{~mm} /$ year). Both regions are elevated 300-600 m above sea level. A more detailed description of the regions is provided by Webb et al. (1997).

What differentiates these 2 regions from others in Queensland and Australia is farmer dependence on forage crops rather than pastures for their feedbase - more than $80 \%$ of the improved pasture or crop area is used for annual fodder crops (Pritchard et al. 1991). This system of farming has been practised for many years. Ashton (1951) noted the following: 'On the eastern Downs dairying and stock-raising generally are associated with crop-growing, and in some areas a succession of fodder crops largely takes the place of 
permanent sown pastures.' This continued dependence on cropping over pasture may be due to a number of factors. First, as already mentioned, climate variability is a dominating feature of the study region and the majority of farms have limited irrigation water $-60 \%$ having none (Kerr et al. 1996). Annual forage crops preceded by fallow periods provide a way for reducing reliance on incidental rainfall and enabling more strategic feed planning. Second, crops have higher potential biomass production per unit area than pastures (Pritchard et al. 1991) and are particularly well suited to fodder conservation - particularly as silage. Third, the cracking clay soils (Vertosols) that dominate both regions are well suited to cropping but have surface characteristics which make the establishment of small-seeded grasses difficult (Leslie 1965).

The sloping lands on which most dairy farms are located have a long history of cropping — some having been continuously cropped for over 100 years (Osborn 1978; Marshall et al. 1988). This cropping has traditionally relied on the inherent fertility of the soil to provide most plant nutrient requirements and tillage to control weeds over the fallow and prepare a fine, residue-free seedbed. These practices expose the soil to erosion, particularly over the summer period (Osborn 1978; Freebairn and Wockner 1986; Marshall et al. 1988; Wylie 1993), and contribute to fertility decline (Dalal and Mayer 1986; Thompson and Bywater 1987) and soil structural decline in some soils (Cook et al.

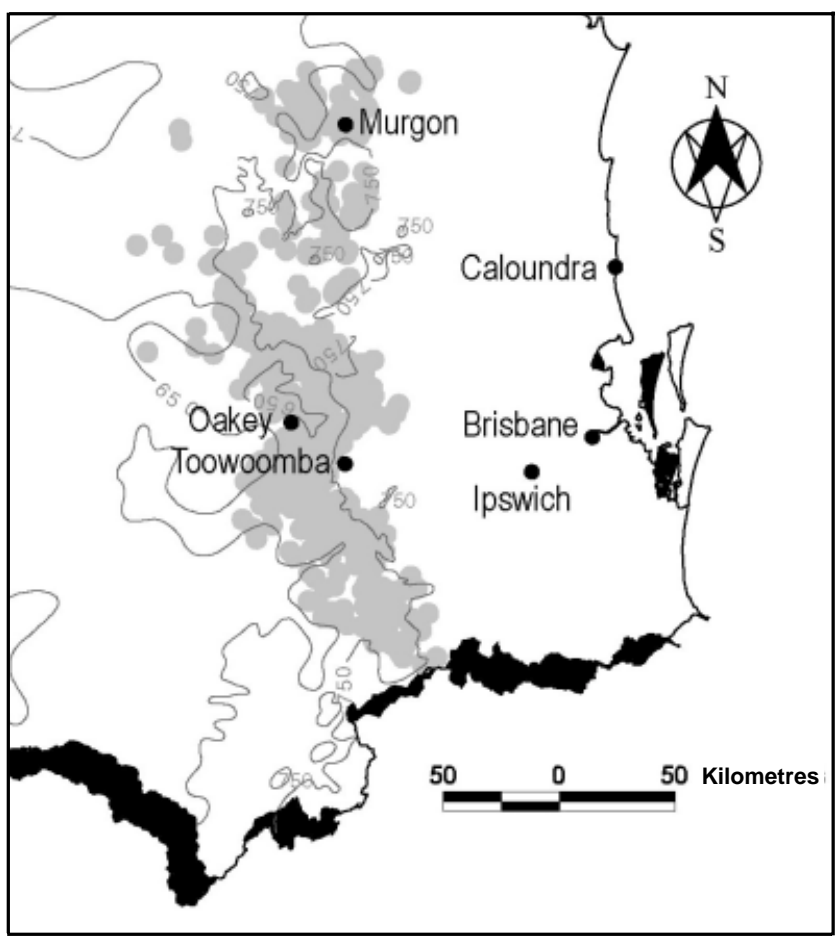

Figure 1. Map of the area surveyed in south-eastern Queensland showing the main towns and rainfall isohyets. Grey circles represent individual farms.
1992; Bridge and Bell 1994). The decline in soil productive capacity is applicable to both grain and forage cropping lands of the study region and has been the focus of a number of studies to better understand and develop strategies to overcome both biophysical (Freebairn and Wockner 1986; Dalal et al. 1995; Connolly et al. 1998) and sociological (Chamala et al. 1983; Blacket and Hamilton 1992; Hamilton $1995)$ constraints to improved farm practices. Grain growers have been the primary focus of these studies.

While common technologies are shared between farmers cropping for grain or for forage for grazing dairy cows, there are some important differences between the 2 systems that need consideration. First, cropping for forage normally takes place on the shallower sloping soils rather than on the deeper soils of the lower slopes and alluvial plains (Marshall et al. 1988), thus increasing the risk and consequences of erosion. Second, multiple grazings of the crop by cattle reduces crop soil cover and increases the chances for soil compaction by cattle, particularly if grazing takes place under wet conditions (Radford et al. 1999). Third, pressure to provide a year-round supply of forage for cattle means that planting often takes place on lower levels of stored soil moisture than would be considered an acceptable risk for grain production.

Management strategies have been developed in the subtropical grains industry that have the potential, when incorporated into farming systems, to contribute to improved sustainability of the soil resource base. These strategies include the use of ley pastures (Littler 1984; Dalal et al. 1995), increased cropping intensity (Wylie 1997), zero tillage (Freebairn and Wockner 1986) and improved fertiliser management (Strong and Holford 1997). Following a number of research and extension activities to address fertility decline on cropping soils on the Darling Downs dairy farms through increased fertiliser rates (Thompson and Bywater 1987; Chataway et al. 1994), it was determined that there was a need for a broader, more strategic approach to this problem. This was identified as a high priority by farmers on the Darling Downs through the Sub Tropical Dairy Program (Chamberlain 2000). In 1996, the Department of Primary Industries (Queensland) was commissioned by the Dairy Research and Development Corporation to undertake such study. The present survey was conducted in February 1997 as part of this study, with the objectives of establishing a benchmark on current farmer practices and attitudes to management strategies being promoted in the grains industry, and of providing further research and extension direction to the project team.

\section{Materials and methods}

The survey used the same database and stratification of farms that was used in an earlier state-wide survey of the Queensland dairy industry undertaken by the Department of Primary Industries in 1995 (Kerr et al. 1996). Additional general information on farming systems and their personnel are provided in this report. We used the same boundaries for defining the Darling Downs and Southern Inland 
Burnett subregions as used in previous dairy surveys (Anon. 1988; Kerr 1996) and that are used by the Sub Tropical Dairy Program (Chamberlain 2000). These boundaries include a small number of farms north of Toowoomba that fall outside the generally accepted geophysical boundaries of the Darling Downs (Anon. 1995) and Southern Inland Burnett (Smith and Dent 1993). These farms tend to be located in a higher rainfall environment and are more pasture-based than the general population. However, we believe that their inclusion gave us the benefit of being able to make direct comparisons between our findings and previous dairy survey work: this outweighed the disadvantages of surveying a less homogeneous population.

Stratification was made on the basis of farm milk production: low $(<350000 \mathrm{~L} /$ year $)$, medium (350000-750000 L/year) and high $(>750000 \mathrm{~L} /$ year). We mailed out questionnaires to $50 \%$ of farmers randomly chosen from within each region by production strata.

The survey was developed in consultation with farmers, dairy advisors and staff from the Rural Extension Centre, Gatton. Initially we considered the use of both focus groups (Patton 1990) and a written survey to gather qualitative and quantitative information, respectively. However, after consideration, we decided that given adequate consultation with farmers and advisors, a written survey could provide all the information we sought. The questionnaire was designed to take farmers no more than $15 \mathrm{~min}$ to complete and included: (i) open-ended questions, which were later codified to test for frequency of responses; (ii) multiple choice type questions; and (iii) questions that required the ranking of statements in level of importance or agreement. Opportunities for further comments were also given in 3 of the 4 sections that comprised the questionnaire.

The questionnaire comprised the following: (i) Part 1 was concerned with ascertaining how farmers currently use land that they consider suitable for cropping, and their attitude toward greater use of pastures in the future. (ii) Part 2 sought information on the level of cropping intensity practiced by farmers. This was ascertained by asking farmers how frequently they double-crop a typical dryland paddock on their farm. We also sought to understand the main reasons, apart from moisture supply, that prevent farmers from growing more than 1 crop per year. To do this, farmers were asked to rank 4 other reasons into their level of importance (often, sometimes or not important). An opportunity was also given for further comments. (iii) Part 3 sought information on farmers' current planting machinery and farmer opinion on the suitability of zero tillage for dairy farms. Opinions were gauged by posing a series of hypothetical statements about zero tillage and seeking farmers' feedback on these statements through ranking them according to their level of agreement. An opportunity for further comments was given. (iv) Part 4 dealt with the issue of plant nutrition. Information was sought on current fertiliser use on dryland oat and sorghum crops, whether fertiliser use had changed over the last 5 years in response to the drought conditions, and the basis on which farmers determined their fertiliser rates. The farmers' opinions were also sought on whether they would be willing to increase fertiliser rates if it was demonstrated that this would improve the sustainability of the soil resource base, and what they saw as the future use of legumes on farms.

To assess questionnaire design before the mail out, a pilot study was conducted with 6 farmers that were considered representative of the projected sample group. Some minor changes were made to the questionnaire before a final draft was mailed out to farmers. A covering letter was included with the survey from the State's senior dairy research scientist. The survey was justified on the grounds that it provided a benchmark in relevant farmer practices and attitudes and would assist the project team in refining the direction of their research and extension activities. Within 12 months of the survey being conducted, a report was sent to all farmers outlining the major findings and actions that had been taken.

Frequency of responses and contingency tables were developed for the collected data and $\chi^{2}$-tests conducted where appropriate to test for common frequency.

\section{Results}

One hundred and twenty farmers returned the questionnaire. This represents a response rate of $40 \%$ of those mailed or $20 \%$ of all producers in the 2 regions. This response rate compares favourably to other mail-out surveys concerned with farmer practice and attitudes to agronomic and resource management issues (Vanclay and Glyde 1994; Hayman and Alston 1999). In our survey, each region was represented in proportion to the producer population and all production strata were represented but there was a bias toward the medium-high-producing farms (Table 1). We appreciate that our respondents may also represent an overall bias toward farmers who are actively interested in the issues that this survey investigates.

For each of the 4 sections of the survey, some questionnaires could not be used due to incompleteness. This did not invalidate the questionnaire from use for other sections. The number of valid responses for Parts 1, 2, 3 and 4 were $113,116,114$ and 111, respectively.

\section{The use of cropping land and attitude to pastures}

The median area of land that farmers considered suitable for cultivation on their properties was 119 ha (range 20-500 ha). Of this area, the median proportion used for annual crops was $87 \%$ (range $0-100 \%$ ). Sixty per cent of respondents said they would like to reduce the area of land devoted to annuals and grow more perennials such as lucerne, grasses or grass and legume mixes. However, there are many reasons why only a limited area of the farm is sown to perennials (Fig. 2).

\section{Cropping intensity (dryland forage crops)}

Ninety-five per cent of respondents grew some area of dryland annual forage crops. Considering the management of 1 fairly typical paddock on the farm, $28 \%$ of respondents

Table 1. Distribution of farmer population and sample size across three production strata

\begin{tabular}{lccc}
\hline $\begin{array}{l}\text { Production stratum } \\
(\times 1000 \text { L/year) }\end{array}$ & $\begin{array}{c}\text { No. of farmers } \\
\text { (population) }\end{array}$ & $\begin{array}{c}\text { No. of farmers } \\
\text { (sample) }\end{array}$ & $\begin{array}{c}\text { Proportion of population } \\
\text { sampled (\%) }\end{array}$ \\
\hline$<350$ & 360 & 62 & 17.2 \\
$350-750$ & 207 & 48 & 23.2 \\
$750+$ & 34 & 10 & 29.4 \\
All & 601 & 120 & 20.0 \\
\hline
\end{tabular}




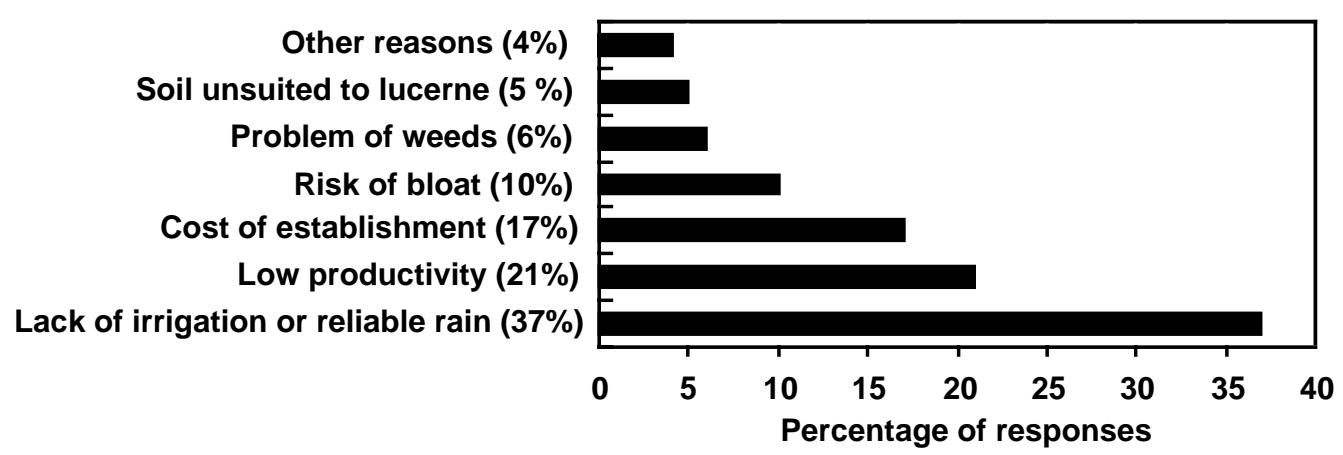

Figure 2. Reasons why farmers don't grow more pastures. Relative importance expressed as a percentage of responses.

stated that they had double-cropped this paddock no more than once in the last 10 years, $51 \% 2$ or 3 times and $21 \% 4$ or more times. When double-cropping, farmers had no particular preference as to whether it was with a summer or a winter crop. Besides insufficient moisture, other reasons for not growing 2 crops and their relative importance are given in Table 2.

The following comments were made by 16 farmers on double-cropping and provide some further insight into attitudes and practices. Most comments related to different strategies for managing risk in a variable rainfall environment. 'Fallow gives best return, but we have to use every chance to grow a crop when it comes - even when we know we are taking a risk' (South Burnett); and conversely, 'The way seasons have been running I feel it is better to leave ground fallow to grow one decent crop per year rather than two half crops' (northern Darling Downs); and 'During the entire 1990's it has been virtually impossible to grow one crop per year let alone double crop. However in more favourable times double-cropping was common either winter to summer and vice versa' (southern Darling Downs). The other remaining issues raised concerned the preference for a grass-legume crop rotation 'If we double-crop we like to double-crop with a legume crop if possible' (northern Darling Downs), and some less tangible values farmers may place on a fallow period, 'Land needs a spell. Therefore double-cropping is not positive' (northern Darling Downs); and 'Weeds can be controlled chemically and fertiliser can be applied but moisture is important to condition soil after dry periods' (northern Darling Downs).

\section{Tillage practices}

When asked to describe their current planter in terms of its ability to function where cultivation is reduced, $54 \%$ of farmers said that their planter required a fully prepared seedbed, 37\% said it was capable of handling some trash and $9 \%$ said it was suitable for zero tillage. The median row spacing of planters was $17.5 \mathrm{~cm}$, trade in value $\$ 2750$ and the age 15 years. With regard to ownership of primary tillage equipment that could be modified into a planting machine suitable for zero-till farming, 9 of every 10 respondents owned a chisel plough or a similar heavy tined implement.

Farmers' response to statements commonly made about zero tillage are given in Table 3. Forty farmers made further comments of which almost half were about soil type, compaction from cattle or the interaction between the two. The compaction of heavy black soils by cattle was seen as problematic. 'A lot of soils are heavy black and where grazed can set hard. I believe it necessary to cultivate these paddocks to prepare a seedbed. On grain paddocks zero till is being used in this area' (southern Darling Downs). 'On heavy black clay soils, wet weather would make it (zero tillage) impossible' (South Burnett). 'Minimum till doesn't really suit where you have cattle trampling black soil' (southern Downs). Five farmers made further comments about herbicides. These comments were negative regarding their increased use 'You have no idea what the long-term

Table 2. Frequency of responses (expressed as a percentage of total responses) as to why, besides insufficient soil moisture, farmers are not growing two crops per year

\begin{tabular}{lcccrr}
\hline Reason & Often important & Sometimes important & Not important & $\chi^{2}$-value & Signif. \\
\hline Insufficient nutrients & 35.5 & 37.0 & 27.5 & 0.14 & n.s. \\
Insufficient time for ground preparation & 45.5 & 43.5 & 11.0 & 20.9 & $* *$ \\
Insufficient opportunity for weed control & 39.5 & 35.0 & 25.5 & 2.9 & n.s. \\
Concern that a fallow is essential for successful & 56.5 & 21.5 & 22.0 & 22.5 & $* * *$ \\
forage production & & & & \\
\hline
\end{tabular}

$* * * P<0.001 ;$ n.s., not significant. 
Table 3. Respondents' attitude towards statements commonly made about zero tillage (expressed as a percentage of total responses)

\begin{tabular}{lcrrrr}
\hline Statement & Agree & Undecided & Disagree & $\chi^{2}$-value & Signif. \\
\hline 'Zero tillage reduces tractor time' & 92.0 & 3.5 & 4.4 & 175.2 & $* * *$ \\
'Extra herbicide puts me off' & 53.2 & 20.7 & 26.1 & 20.1 & $* * *$ \\
'Zero tillage allows you to make better use of soil moisture' & 65.8 & 21.1 & 13.2 & 20.1 & $* * *$ \\
'On my soils zero till would not be suitable' & 38.3 & 29.6 & 32.2 & 1.3 & n.s. \\
'When you've got cattle you'll always need to plough the soil' & 63.2 & 15.8 & 21.1 & 46.1 & $* * *$ \\
'Soil structure improves with zero till' & 41.7 & 41.7 & 16.5 & 14.6 & $* * *$ \\
'Reducing tillage reduces erosion' & 75.7 & 12.2 & 12.2 & 92.6 & $* * *$ \\
'The cost to change over to a planter suitable for zero tillage work would be just & 55.1 & 26.2 & 18.7 & 23.7 & $* * *$ \\
too much at the moment' & & & & \\
\hline
\end{tabular}

$* * * P<0.001 ;$ n.s., not significant.

effects are on the soil or human beings when you use a lot of chemicals' (central Darling Downs). One farmer did raise the unrelated, but important issue, as to whether grazed forage systems generated adequate crop residue for zero-till farming. 'In our dairying situation there is seldom much trash for ground cover' (central Darling Downs).

\section{Plant nutrition}

Compared with the rate of fertiliser being applied 5 years ago, before the current drought, the majority of farmers $(57 \%)$ stated that they had not changed their fertiliser use. Of the remaining farmers, half had increased fertiliser use while the other half had decreased it.

Farmers are heavily reliant on their own observations of crop performance to determine fertiliser use. Farmers were asked to consider 4 strategies that may be used to determine fertiliser use: advice from a fertiliser supplier or agent; an independent consultant; a dairy adviser; or their own observations. Fifty-three percent of respondents relied solely on their own observations. A further 34\% used their own observations in combination with advice from 1 or more relevant off-farm agents (dairy advisers, fertiliser suppliers and/or agent or independent consultants), while 13\% relied primarily on outside expertise rather than their own observations.

If it was demonstrated that sustainability of the soil resource base would be improved and profitability not reduced through the use of higher fertiliser rates, $56 \%$ of respondents said they would increase their application rate, $27 \%$ were undecided as to what they would do and $17 \%$ said they would not change their rate of application (Table 4).
In 5 years time, $65 \%$ of respondents believe they will be growing more legumes and only $1 \%$ that they will be growing less. The remaining farmers believe they will be growing about the same. Most of this extra legume grown will come from annual summer crops $(41 \%)$ or lucerne $(33 \%)$.

\section{Discussion}

\section{The use of cropping land and attitude to pastures}

As in previous studies, most land that farmers consider suitable for cropping is used for growing annual forages rather than improved pastures (Anon. 1988; Ashwood et al. 1993). The survey did not seek to identify the reasons for the wide variation between farms on the area of land that is considered suitable for cropping nor for the proportion of that area devoted to cropping. However, there is significant variation within the study region in terms of herd size (Kerr et al. 1996) and geophysical attributes of farms. While no clear comparison between dairy, grain and mixed farming enterprises can be made, there is evidence to suggest (Chamala et al. 1983) that the median cultivated area on dairy farms is somewhat less than these other enterprises.

The major impediment to greater use of pastures, that is the lack of irrigation or reliable rain (Fig. 2), indicates that farmers view annual forage crops as being less sensitive to this regional constraint. Forage crops are traditionally grown in either winter or summer with a period of fallow in the opposing season (Ashwood et al. 1993). The accumulation of moisture and nutrient release over the fallow enables farmers to develop feed year programs with more confidence than if they were solely reliant on pasture growth from

Table 4. Current fertiliser application rates practised by farmers on dryland forage crops

\begin{tabular}{lcccc}
\hline Element & $\begin{array}{c}\text { Applied to forage sorghum (kg/ha) } \\
\text { Median }\end{array}$ & Range & $\begin{array}{c}\text { Applied to forage oats (kg/ha) } \\
\text { Median }\end{array}$ & Range \\
\hline Nitrogen & 46 & $0-140$ & 40 & $0-140$ \\
Phosphorus & 0 & $0-28$ & 0 & $0-28$ \\
Potassium & 0 & $0-20$ & 0 & $0-20$ \\
Sulfur & 0 & $0-25$ & 0 & $0-25$ \\
\hline
\end{tabular}


incidental rainfall. Additional factors that may favour annual crops over pastures include the difficulties in establishing small-seeded pasture grasses under rain-grown conditions on clay soils (Leslie 1965; Thompson 1988; Buchanan and Cowan 1990), the improved forage quality and flexibility of sorghum and millet species as a result of intensive plant breeding (Stuart 1990), the availability of non-bloating, large-seeded annual legumes such as lablab (Lablab purpureus) and the lack of any perennial pastures that can fill the winter feed gap on dryland dairy farms (Thompson 1988). Lucerne (Medicago sativa) is one perennial species that is well suited to the study region due to its drought tolerance, ability to produce high quality forage (Minson et al. 1993) and fix large quantities of nitrogen (Lloyd et al. 1991; E. J. Weston, R. C. Dalal, W. M. Strong, K. L. Lehane, J. E. Cooper, A. J. King and C. J. Holmes, unpublished data). Its limitations include intolerance to waterlogging, risk of bloat to grazing animals (Thompson 1988) and increased risk of cereal crops immediately after suffering water stress (Dalal et al. 1991). In addition, farmers raised questions regarding its productivity, 'lucerne hasn't the amount of feed that forage crops have in dry land'; 'we are not able to get enough growth for silage or hay as compared with cropping'; 'dryland lucerne is a feast or a famine and in irrigation it is an inefficient user of water'. While it is reasonable to assume that the periods of prolonged drought between 1990 and 1994 have highlighted farmers' concern about reliable rain, climate variability is an inherent feature of the region.

It is clear that any development and extension project seeking to expand the role of pastures as a soil-fertility restorative practice will need to investigate and address these issues further with farmers. The strong indication from respondents is that benefits that come from pastures in terms of soil fertility gains (Littler 1984; Hossain et al. 1996), soil structure (Dalal et al. 1991; Waters and Oades 1991) and reduced erosion (Freebairn and Wockner 1986) will be offset by lower farm productivity and increased risk taking.

\section{Cropping intensity}

Despite extended periods of drought between 1990 and 1994 in the study region (Clewett et al. 1999), most respondents $(72 \%)$ had double-cropped dryland paddocks at least 2 or 3 times over the last 10 years. This indicates that most farmers are familiar with, and are practitioners of opportunistic double-cropping. At least some of this double-cropping would be associated with moving from summer to winter crops and vice versa: this practice having replaced the use of long fallows on the eastern Darling Downs (Chamala et al. 1983; Blacket and Hamilton 1992). Respondents varied in their opinion on the merits or otherwise of opportunity double-cropping versus growing a single crop after a fallow period. However, we would suggest that attitudes toward a fallow period indicated support for the notion that double-cropping is practised more out of necessity than in the belief that it is a better way to farm. This view is supported by Blacket and Hamilton (1992) who found, in focus group work with Oakey grain and dairy farmers, that double-cropping was being practiced in response to economic pressure and not because farmers saw it as a better way to farm. 'Economics means farmers have to double crop and this is not regarded as being sustainable'. This view that double-cropping is exploitative and unsustainable is at variance with the view that opportunistic double-cropping is an affirmative action toward minimising erosion, particularly on the sloping country of the eastern Darling Downs which receives higher annual rainfall than the plains further west and has soils with lower available soil water capacity (Wylie 1997).

Of the single issues preventing farmers from double-cropping, insufficient time for ground preparation is slightly more important than others (Table 2). A zero-till planter's ability to establish a crop in a non-conventional seedbed is a potential solution to this issue. However, the success of the planting operation will be dependent on the ability of the planter to handle stubble and compacted soil. Too much compaction may make it difficult to achieve satisfactory plant establishment. Farmers saw insufficient nutrients and opportunity for weed control as other important reasons for not growing more crops. Freebairn et al. (1997) noted that higher management inputs are generally needed with more intensive cropping systems and weed control can become an important limitation. The management flexibility of forage crops (Muldoon 1984) makes them well suited to double-cropping. Crops can be terminated with herbicides after being grazed once or twice to enable a short period of fallowing before the planting of the next crop. However, as forage crops have potentially long growing seasons (French 1981) - particularly with the more recent development of later flowering forage sorghum (Stuart 1990) and oat varieties - there may not be the same economic benefits to be achieved in the grain industry with opportunistic double-cropping (Wylie 1997).

\section{Tillage practices}

Minimal- and zero-tillage farming has been demonstrated to have both economic and soil conservation benefits in the subtropical cereal belt (Freebairn and Wockner 1986; Radford et al. 1995).

In our survey we found that only a small percentage of farmers own a planter capable of zero tillage (9\%), while a larger group have planters with some residue-handling capability. This second group of planters are commonly known as trashseeders and are capable of planting through more stubble than a conventional combine (Crothers and Graham 1995). This ability makes them useful in a stubble-mulch system which can reduce erosion (Freebairn and Wockner 1986). However, similarly to conventional 
planters their row spacing is narrow $(150-200 \mathrm{~mm})$, which limits the use of press wheels. Also, due to insufficient tine breakout pressure, they only have a limited ability to plant into firmer seedbeds. However, the survey showed that $90 \%$ of farmers own a heavy-tined implement that can be modified relatively inexpensively into a planting machine suitable for minimal- or zero-till cropping (Greenaway 1997).

With respect to respondents' attitudes to zero tillage (Table 3), there is a wide general agreement on some of the benefits, namely that it reduces tractor time $(92 \%)$ and erosion $(75 \%)$, and it allows you to make better use of soil moisture $(66 \%)$. However, other issues need to be dealt with to enable farmers to achieve these benefits. The potential negative interaction between cattle, soil type and the weather is of particular concern. This management complex needs to be specifically investigated and reviewed as it is somewhat unique to the dairy industry. Strategies that minimise herbicide usage and/or reduce real or perceived long-term herbicide risks would also be beneficial. Blacket and Hamilton (1992) identified concerns about farm chemicals as a major blockage to minimum- and zero-till farming. These concerns included cost, 'soil build-up', impact on human health and reliability of control.

\section{Plant nutrition}

Fertiliser use has remained relatively unchanged since the last major survey in 1987 (Anon. 1988). Of interest is that almost $80 \%$ of farmers have maintained or increased their fertiliser application rates over a period that has encompassed some very unfavourable seasonal conditions. This gives some indication of farmers' confidence in the benefits gained from fertiliser use and/or their preference $(57 \%)$ for a routine rather than tactical approach to fertiliser application.

It is also interesting that nitrogen fertiliser is applied at similar rates to both winter and summer grass-forage crops. On the eastern Darling Downs, Sorghum spp. has shown a more consistent response to higher nitrogen application rates under rain-grown conditions than oats (Mackenzie et al. 1982; Thompson and Bywater 1987; Chataway et al. 1994). Similar rates of fertiliser application may reflect farmers' response to a number of issues including: an effort to overcome the nutritional disease 'red tipping' of oats (Thompson and Bywater 1987); the placement of a higher value on oats due to the lack of winter forage alternatives; or a response to winter milk-price incentives. Alternatively, there may be a genuine failure of farmers to recognise and exploit the high yield potential of Sorghum spp. in this summer-dominant rainfall environment.

Apart from nitrogen fertiliser, farmers apply few other nutrients (Table 4). Despite the high inherent fertility of most arable soils on the Darling Downs and South Burnett (Webb et al. 1997) and the potential input of nutrients onto the farm through purchased supplementary feeds, this practice may not be sustainable over the long term. That more than half the respondents stated that they would increase fertiliser rates if this would improve the sustainability of the resource base, indicates a willingness of farmers to reassess their current practices if necessary. The survey showed that farmers rely heavily on their own observations of the crop's performance to determine fertiliser rates. The important role that local technical knowledge plays in crop agronomy needs to be considered in any research and development project and could be used as a platform for productive interactions between scientists and farmers. Work conducted with dairy farmers in fertiliser management needs to be cognisant of the lessons coming from the grain industry that farmers favour simple over complex approaches to nitrogen management (Hayman and Alston 1999). With respect to the role of legumes in soil fertility management, Blacket and Hamilton (1992) found that farmers would prefer to rectify protein decline through legume rotations rather than with fertiliser nitrogen. The strong agreement amongst farmers in this survey that in 5 years time they will be growing at least the same or a greater area of legumes supports this notion. For dairy farmers, the competitive advantage of growing legumes for forage increases as soil nitrogen declines. A non-bloating legume such as Dolichos purpureus provides high-quality forage, does not need fertiliser nitrogen inputs and may provide some carry over benefits to following crops.

Finally, the greater use of legumes may have secondary implications for soil organic matter levels as legume crops produce smaller quantities of carbonaceous residue than their summer cereal counterparts.

\section{Conclusions}

By providing specific insights from farmers cropping for forage rather than for grain production, this study adds to earlier work undertaken on farmer practices and attitudes to landuse management in southern Queensland (Chamala et al. 1983; Blacket and Hamilton 1992). Information gained in this study can be used to better formulate research questions and temper future extension activities that involve an animal component in the cropping production system. For dairy farmers, it is clear that while they are familiar with the potential benefits of technologies that have been developed for the grain industry, some of these strategies need further investigation to ensure their applicability for intensivegrazing animal production. This work needs to be conducted in a manner that allows outcomes to be assessed for both their ability to meet natural resource management goals and the broader needs of farmers. Farming Systems Research (Petheram and Clarke 1998), with its emphasis on multidisciplinarity, participation and holism, may provide a suitable framework to achieve these goals. 


\section{Acknowledgments}

This study was supported by funds from the Dairy Research and Development Corporation and made possible by the cooperation of 120 farmers who took the time to complete the survey.

\section{References}

Anon. (1988) 'Queensland dairy farmer survey 1986-87.' Queensland Department of Primary Industries, Brisbane.

Anon. (1995) 'Farming in the Darling Downs Region.' (Department of Primary Industries, Queensland: Toowoomba, Qld)

Ashton LG (1951) 'Dairy farming in Australia - Queensland edition.' (Commonweath Department of Commerce and Agriculture: Sydney)

Ashwood A, Kerr D, Chataway RG, Cowan TM (1993) Northern Dairy Feedbase 2001. 5. Integrated dairy farming systems for northern Australia. Tropical Grasslands 27, 212-228.

Blacket D, Hamilton G (1992) 'Understanding farmer decision making on land use: research using focus groups in southern Queensland.' Queensland Department of Primary Industries, SQA 92006, Goondiwindi, Qld.

Bridge BJ, Bell MJ (1994) Effect of cropping on the physical fertility of krasnozems. Australian Journal of Soil Research 32, 1253-1273.

Buchanan I, Cowan RT (1990) 'Pasture response to nitrogen fertiliser on dairy farms in south east Queensland (Project MPY-DH 13 final report).' Department of Primary Industries, Brisbane.

Chamala S, Coughenour CM, Keith KJ (1983) 'Study of conservation croppping on the Darling Downs - a basis for extension programming.' Department of Agriculture, University of Queensland, Brisbane.

Chamberlain P (2000) Outcomes from farmer defined research priorities. In 'AAAP-ASAP satellite conference'. Gatton. (Ed. T Cowan) pp. 46-53. (University of Queensland: Gatton, Qld)

Chataway RG, Orr WN, Cowan RT, Franz AJ, Buchanan IK, Long PL (1994) 'Milk responses to nitrogen fertiliser applied to dryland forage crops in south east Queensland. Final report, Project DAQ066.' Dairy Research and Development Corporation, Melbourne.

Clewett JF, Smith PG, Partridge DA, George DA, Peacock A (1999) 'Australian Rainman Version 3: an integrated software package of rainfall information for better management.' (Department of Primary Industries Queensland: Brisbane)

Connolly RD, Freebairn DM, Bell MJ (1998) Change in soil infiltration associated with leys in south-eastern Queensland. Australian Journal of Soil Research 36, 1057-1072.

Cook GD, So HB, Dalal RC (1992) Structural degradation of Vertisols under continuous cultivation. Soil and Tillage Research 22, 47-64.

Crothers T, Graham D (1995) 'Trashseeders for conservation cropping.' Department of Natural Resources, DNRQ 97033, Brisbane.

Dalal RC, Mayer RJ (1986) Long-term trends in fertility of soils under continuous cultivation and cereal cropping in southern Queensland. II. Total organic carbon and its rate of loss from the soil profile. Australian Journal of Soil Research 24, 281-292.

Dalal RC, Strong WM, Weston EJ, Cooper JE, Leahane KJ, King AJ, Chicken CJ (1995) Sustaining productivity of a Vertisol at Warra, Queensland, with fertilisers, no-tillage, or legumes. 1. Organic matter status. Australian Journal of Experimental Agriculture 35, 903-913.

Dalal RC, Strong WM, Weston EJ, Gaffney J (1991) Sustaining multiple production systems. 2 . Soil fertility decline and restoration of cropping lands in sub-tropical Queensland. Tropical Grasslands 25, 173-180.
Freebairn DM, Connolly RD, Dimes J, Wylie PB (1997) Crop sequencing. In 'Sustainable crop production in the sub-tropics: an Australian perspective.' (Eds AL Clarke, PB Wylie) pp. 289-305. (Department of Primary Industries, Queensland: Brisbane)

Freebairn DM, Wockner GH (1986) A study of soil erosion on vertisols of the eastern Darling Downs, Queensland. 1. Effect of surface conditions on soil movement with contour bay catchments. Australian Journal of Soil Research 24, 135-158.

French AV (1981) Forage sorghums. In 'Forage crops and regional forage systems in Queensland'. Toowoomba Workshop, 20-22 May 1980. (Queensland Department of Primary Industries)

Greenaway J (1997) 'Different implements for a different seedbed.' Department of Primary Industries, Agdex No. 100/741 1997, Dalby, Qld.

Hamilton NA (1995) Learning to learn with farmers. An adult learning extension project. PhD Thesis, Landbouw University, Wageningen.

Hayman PT, Alston CL (1999) A survey of farmer practices and attitudes to nitrogen management in the northern New South Wales grain belt. Australian Journal of Experimental Agriculture 39, 51-63.

Hossain SA, Dalal RC, Waring SA, Strong WM, Weston EJ (1996) Comparison of legume-based cropping systems at Warra, Queensland. 1. Soil nitrogen and organic carbon accretion and potentially mineralisable nitrogen. Australian Journal of Soil Research 34, 273-287.

Johnsson NN (1997) Control of cattle tick (Boophilus microplus) on Queensland dairy farms. Australian Veterinary Journal 75, 802-807.

Kerr D, Davison T, Hetherington G, Lake M, Murray A (1996) 'Queensland dairy farm survey 1994-95.' Queensland Department of Primary Industries, QI96115, Brisbane.

Leslie JK (1965) Factors responsible for failures in the establishment of summer grasses on the black earths of the Darling Downs, Queensland. Queensland Journal of Agricultural and Animal Sciences 31, 317-327.

Littler JW (1984) Effect of pasture on subsequent wheat crops on a black earth of the Darling Downs. 1. The overall experiment. Queensland Journal of Agricultural and Animal Sciences 41, 1-12.

Lloyd DL, Smith KP, Clarkson NM, Weston EJ, Johnson B (1991) Sustaining multiple production systems. 3. Ley pastures in the subtropics. Tropical Grasslands 25, 181-188.

Mackenzie J, Mayer R, Bisset WJ (1982) Productivity of five subtropical grasses on a black earth of the eastern Darling Downs in Queensland. Tropical Grasslands 16, 170-180.

Marshall JP, Crothers RB, Macnish SE, Mullins JA (1988) 'Land management field manual south-east Darling Downs Districts.' (Department of Primary Industries, Queensland Government: Brisbane)

Minson DJ, Cowan T, Havilah E (1993) Northern dairy feedbase 2001. 1. Summer pasture and crops. Tropical Grasslands 27, 131-149.

Muldoon DK (1984) Self regenerating annual forage legumes for double cropping with irrigated wheat or sorghum. Experimental Agriculture 20, 319-326.

Osborn RC (1978) The need for land use planning in the Darling Downs Region. In 'Agricultural engineering conference 1978'. Toowoomba, Qld. pp. 171-174. (Association of Engineers: Barton, ACT)

Patton MQ (1990) 'Qualitative evaluation and research methods.' (Sage Publications Inc.: Newbury Park, CA)

Petheram RJ, Clarke RA (1998) Farming systems research: relevance to Australia. Australian Journal of Experimental Agriculture 38, 101-115. 
Pritchard K, Havilah E, McRae C, Thompson P (1991) Fodder Crops. In 'Feedbase 2000'. (Eds B Bartsch, W Mason) pp. 47-58. (CSIRO: Melbourne)

Radford BJ, Key AJ, Robertson LN, Thomas GA (1995) Conservation tillage increases soil water storage, soil animal populations, grain yield, and response to fertiliser in the semi-arid subtropics. Australian Journal of Experimental Agriculture 35, 223-232.

Radford B, Yule D, Rohde K, Sunnerdale R, Barnes A (1999) 'Brigalow Research Station technical report 1998-99.' Department of Primary Industries, Qld, Information Series Q199068, Brisbane.

Rosenthal KM, White BJ (1980) 'Distribution of a rainfall erosion index in Queensland.' Division of Land Utilisation, Queensland Department of Primary Industries, 80/8, Brisbane.

Smith GK, Dent DJ (1993) Field manual. In 'Understanding and managing soils in the inland Burnett District'. (Ed. JM Maher). Department of Primary Industries Training Series QE93001, Brisbane.

Strong WM, Holford IC (1997) Fertilisers and manures. In 'Sustainable crop production in the sub-tropics: an Australian perspective'. (Eds AL Clarke, PB Wylie) pp. 214-235. (Department of Primary Industries, Queensland: Brisbane, Qld)

Stuart PN (1990) 'The forage book.' (Pacific Seeds: Toowoomba, Qld)

Thompson P (1988) 'Improving livestock profitability with pasture and forage crops.' (Bowdler, English and Wehl Seed and Grain and Annand, Robinson and Co.: Toowoomba, Qld)

Thompson PJM, Bywater JW (1987) Red tipped oats. Queensland Agricultural Journal 113, 165-170.
Vanclay F, Glyde S (1994) 'Land degradation and land management in Central NSW - farmer's knowledge, opinions and practice.' (Centre for Rural Social Research, Charles Sturt University: Wagga Wagga)

Waters AG, Oades JM (1991) Organic matter in water-stable aggregates. In 'Advances in soil organic matter research: the impact on agriculture and the environment'. (Ed. WS Wilson). pp. 163-174. (Royal Society of Chemistry: Cambridge)

Webb AA, Grundy MJ, Powell B, Littleboy M (1997) The Australian sub-tropical cereal belt: soils, climate and agriculture. In 'Sustainable crop production in the sub-tropics: an Australian perspective'. (Eds AL Clarke, PB Wylie) pp. 8-23. (Department of Primary Industries, Queensland: Brisbane)

Wylie P (1993) Conservation farming systems for the summer rainfall cereal belt. Australian Journal of Soil and Water Conservation $\mathbf{6}$, 28-33.

Wylie PB (1997) Integrated farming systems. In 'Sustainable crop production in the sub-tropics: an Australian perspective'. (Eds AL Clarke, PB Wylie) pp. 320-328. (Department of Primary Industries, Queensland: Brisbane)

Received 2 November 2001, accepted 26 November 2002 